- № 2. - С. 5-27. 9. Семеног О. М. Професійна підготовка майбутніх учителів української мови і літератури : [монографія] / Олена Миколаївна Семеног. - Суми : Мрія-1, 2005. - 404 с.

\title{
МОДЕЛЬ ФОРМУВАННЯ УПРАВЛІНСЬКОЇ КОМПЕТЕНТНОСТІ МАЙБУТНІХ ОФІЦЕРІВ ПОЖЕЖНОЇ БЕЗПЕКИ У ПРОЦЕСІ ПРОФЕСІЙНОЇ ПІДГОТОВКИ
}

Король В. М. Модель формування управлінської компетентності майбутніх офіцерів пожежної безпеки у процесі професійної підготовки.

У статті подається методологічне та теоретичне обгрунтування моделі формування управлінської компетентності майбутніх офіцерів пожежної безпеки у процесі професійної підготовки на засадах суб'єктно-діяльнісного та компетентнісного підходів, стисло розкрито зміст кожного їі компонента.

Ключові слова: педагогічна модель, формування, управлінська компетентність, педагогічні умови, компонент.

Король В. М. Модель формирования управленческой компетентности будущих офицеров пожарной безопасности в процессе профессиональной подготовки.

В статье предложено методологическое и теоретическое обоснование модели формирования управленческой компетентности будущих офицеров пожарной безопасности в процессе профессиональной подготовки на основе субъектно-деятельностного и компетентностного подходов, кратко раскрыто содержание каждого ее компонента.

Ключевые слова: педагогическая модель, формирование, управленческая компетентность, педагогические условия, компонент.

Korol V. The model of the formation of the management competence of future officers of fire safety in the process of their professional training.

Methodological and theoretical grounding of the model of the formation of the management competence of future officers of fire safety in the process of their professional training on the basis of the subjective, activity and competence approaches is dealt in the article. The author of the article reveals the sense of its every component.

Key words: pedagogical model, formation, management competence, pedagogical conditions, component.

Науково-педагогічне забезпечення формування управлінської компетентності майбутніх офіцерів пожежної безпеки у процесі професійної підготовки передбачає обгрунтування комплексу спеціальних організаційно-педагогічних заходів, засобів та умов, до складу якого, як правило, входять педагогічні системи, моделі, умови, технології, методики тощо. Одним 3 ефективних засобів формування в них управлінської компетентності $\epsilon$ моделювання, яке в філософії розуміється як метод пізнання, а в педагогіці - як інструмент пізнавальної діяльності, як педагогічний засіб. «Модель - це образ певної системи» [1, с. 196], яка становить певну систему, що складається із взаємопов'язаних компонентів. Педагогічна модель - це узагальнений, абстрактно-логічний образ певного феномена досліджуваного педагогічного явища, який відображає та репрезентує його суттєві змістові, структурні та функціональні зв'язки, а педагогічне моделювання в нашому дослідженні - це розроблення узагальненого, абстрактно-логічного образу управлінської компетентності офіцерів пожежної безпеки і процесу іiі формування.

Mema cmammi: подати методологічне та теоретичне обгрунтування моделі формування управлінської компетентності в майбутніх офіцерів пожежної безпеки у процесі професійної підготовки на засадах суб'єктно-діяльнісного та компетентнісного підходів. 
Проблемні питання професійної підготовки майбутніх фахівців для МНС України містяться в наукових доробках О. Бикової, М. Варія, О. Свсюкова, М. Козяра, М. Коваля, О. Парубка, О. Тімченка, Т. Ткаченка та інших.

Аналіз дисертаційних досліджень, у яких використовується метод моделювання у процесі управлінської підготовки майбутніх фахівців, показує, що основними компонентами (блоками, складовими, елементами) переважної більшості з них є цільовий, мотиваційний, змістовий, процесуальний i результативний. Вони, 3 одного боку, відображають загалом універсальну модель управлінської підготовки будь-якого фахівця, а 3 іншого, - недостатньо враховують специфіку професійної підготовки конкретного фахівця та його посадове призначення. Суттєвими аспектами їх побудови є, на нашу думку, те, по-перше, на яких концепціях і методологічних принципах вони грунтуються; по-друге, яке їх функціональне призначення.

У зв'язку з цим нами на основі врахування вимог суб'єктно-діяльнісного та компетентнісного підходів, принципу системності модель розуміється як сукупність закономірних, функціонально, процесуально i змістовно пов'язаних між собою компонентів, які створюють педагогічну систему та забезпечують формування управлінської компетентності офіцерів пожежної безпеки. Визначені нами компоненти моделі формування управлінської компетентності в процесі професійної підготовки (методологічний, цільово-мотиваційний, змістовий, організаційно-діяльнісний, діагностичний, результативний і суб'єктний) надають змогу більш чітко уявити його цілеспрямований характер та усвідомити необхідність організаційно-управлінського супроводження цього процесу з боку педагогів.

У процесі іiі моделювання нами враховано: вимоги державного стандарту до підготовки фахівців за напрямом 6.170203 «Пожежна безпека» та спеціальностями 7.17020301, 8.17020301 «Пожежна безпека», а також посадові обов'язки випускників ВНЗ МНС України згідно з Довідником кваліфікаційних характеристик професій працівників МНС України; наявність концептуальної основи; необхідність цілеспрямованого формування управлінської компетентності та суб'єкта екстремального виду управлінської діяльності; основні критерії та показники оцінювання сформованості управлінської компетентності.

Під моделлю формування управлінської компетентності в майбутніх офіцерів пожежної безпеки у процесі професійної підготовки ми розуміємо сукупність закономірних, функціонально, процесуально i змістовно пов'язаних між собою компонентів їхньої професійної підготовки, які створюють систему управлінської підготовки та забезпечують отримання інтегрального результату цієї підготовки формування управлінської компетентності. Вона надає змогу здійснити описову характеристику їх управлінських знань, навичок, умінь і здатностей, професійно важливих якостей, ставлення до майбутньої управлінської діяльності, а також концептуальні підходи, педагогічні умови, основні етапи, види управлінської підготовки, принципи, методики, технології, форми та засоби їх формування в процесі професійної підготовки (рис. 1).

Її основні характеристики: інтегральність (це результат викладання не однієї чи кількох навчальних дисциплін, а інтегральний результат всієї професійної підготовки); цілісність, оскільки всі компоненти між собою взаємопов'язані, взаємозумовлені та «працюють» на сумарний результат - сформованість управлінської компетентності; відкритість (з одного боку, враховує вимоги замовника до управлінської підготовки випускника, а з іншого, - можна вносити корекцію, уточнення та вдосконалення в процесі реалізації моделі); суб'єктність (спрямованість на формування суб'єкта екстремального виду управлінської діяльності); професійна спрямованість (зорієнтованість на набуття управлінської компетентності як важливого складника професійної компетентності випускника). 
Водночас вона має певні особливості. Першою ії особливістю є те, що висхідним компонентом $€$ методологічний, який концептуально визначає смислове наповнення інших компонентів.

Вона обгрунтована на засадах, провідних ідеях і положеннях суб'єктно-діяльнісного та компетентнісного підходів, оскільки маємо формувати суб'єкта екстремального виду діяльності - офіцера пожежної безпеки, який здатний компетентно реалізовувати свої основні посадові компетенції після випуску з ВНЗ МНС України. Водночас у процесі іiі обгрунтування враховано окремі принципи системного підходу, оскільки формування управлінської компетентності ми розуміємо як цілісну педагогічну систему, яка має свої структуровані та взаємопов'язані елементи. Суттєвим доповненням є генетичний аспект моделі, оскільки формування управлінської компетентності відбувається протягом всієї його професійної підготовки.

Другою особливістю є те, що вона містить інтегральний компонент - суб'єктний, тобто суттєва увага звертається на особистість курсанта та на його активну життєву, навчальну та професійну позицію, на ставлення до навчальної та майбутньої професійної діяльності в системі МНС як суб'єкта управлінської діяльності. Отже, активність курсанта в навчальній діяльності та його позитивне ставлення до набуття компетентності в управлінській діяльності є важливою умовою ефективності обгрунтованої нами моделі.

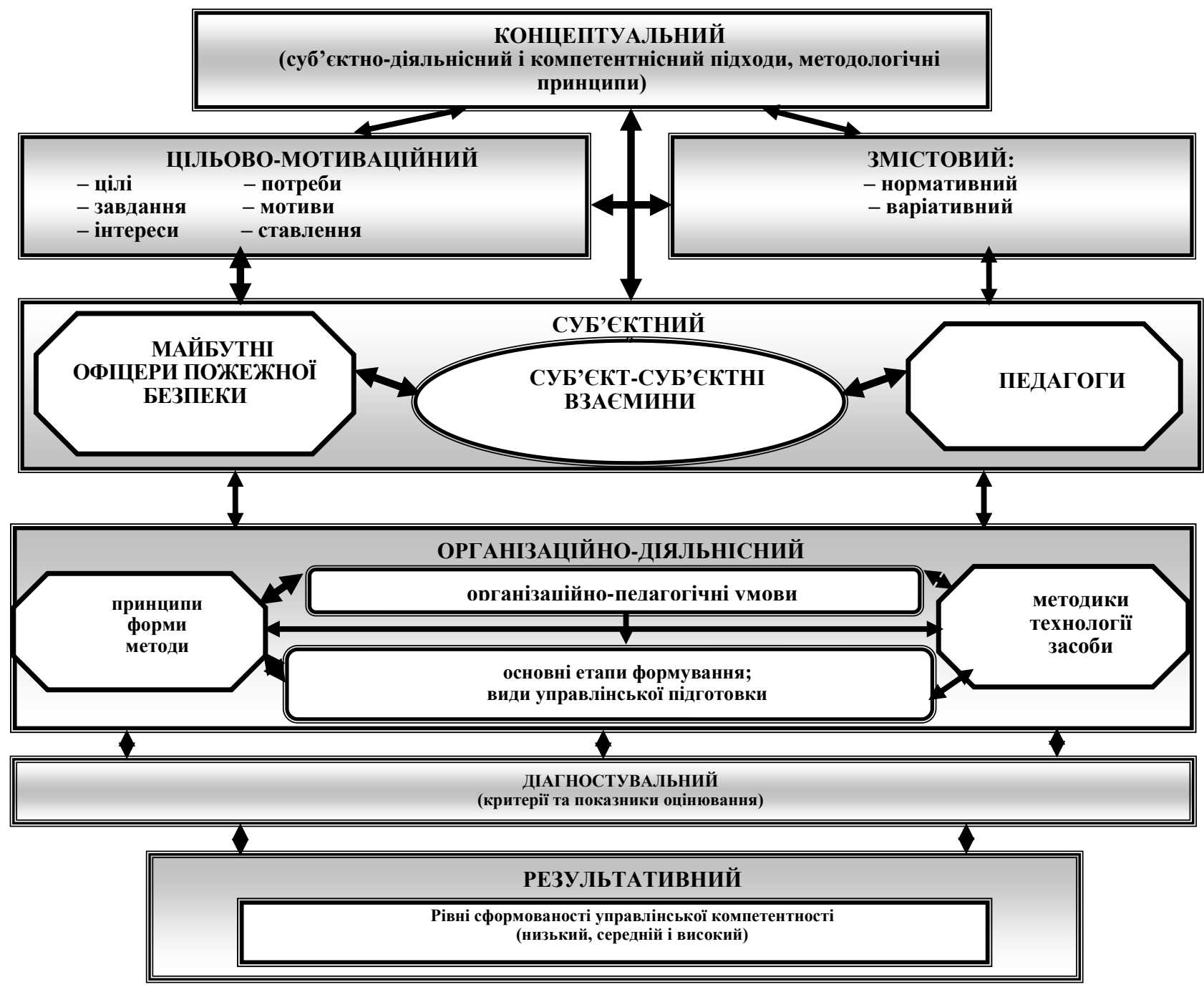

Рис. 1. Суб’єктно-діяльнісна модель формування управлінської компетентності у майбутніх офіцерів пожежної безпеки

На нашу думку, педагогічно доцільна реалізація цієї моделі здатна забезпечувати 
формування їх управлінської компетентності як інтегрального результату професійної підготовки, оскільки їх майбутні посадові обов'язки переважно мають організаційноуправлінський характер. При цьому ми враховували такі обставини: по-перше, у майбутніх офіцерів пожежної безпеки, як суб'єктів управлінської діяльності, формування управлінської компетентності відбувається в процесі професійної підготовки, а зміст управлінської підготовки міститься у всіх циклах навчальних дисциплін; по-друге, їх майбутня управлінська діяльність відбувається як у стандартних, так і в екстремальних умовах, що висуває підвищені вимоги до їхньої управлінської підготовки, цілеспрямоване формування особистісної, психологічної та професійної готовності до стійкої діяльності в екстремальних ситуаціях; по-третє, як показує аналіз ОКХ за напрямом 6.170203 «Пожежна безпека» та за спеціальностями 7.17020301, 8.17020301 «Пожежна безпека» зі спеціалізацій «Організація протипожежного захисту та техніка безпеки», «Системи пожежної, охоронної та технологічної автоматики», «Організація пожежогасіння та рятувальних робіт», «Профілактика пожеж», у ній недостатньо передбачено управлінські вміння та здатності. Хоча аналіз первинних посад, на які вони призначають після закінчення ВНЗ МНС України, наприклад, аналіз посадових обов'язків начальників караулів і державного інспектора 3 пожежного нагляду, інженерного складу органів управління оперативно-рятувальної служби цивільного захисту, згідно з Довідником кваліфікаційних характеристик професій працівників МНС України [2], показує їх насиченість управлінськими обов'язками.

Більш докладно проаналізуємо кожен із компонентів.

Методологічний компонент є вирішальним у нашій моделі, оскільки він визначає концептуальне наповнення ідеями, принципами та цінностями суб'єктно-діяльнісного та компетентнісного підходів всіх інших іiі компонентів. Ці два підходи між собою безпосередньо взаємопов'язані та мають взаємовплив, оскільки, по-перше, слід формувати фахівця екстремального виду діяльності як суб'єкта управлінської діяльності; по-друге, ефективними методиками та технологіями формування практичних здатностей до управлінської діяльності, набуття управлінського мислення $є$ діяльнісні методики та технології; по-третє, для розв'язання типових i нетипових управлінських завдань необхідно набути управлінські знання, навички, вміння, здатності, формувати професійно важливі якості, мати позитивне ставлення до майбутньої управлінської діяльності, що називається управлінською компетентністю; по-четверте, ці два підходи визначають стрижньовий соціально-психологічний механізм функціонування нашої моделі - це суб'єкт-суб'єктні взаємини між педагогами та курсантами, між самими курсантами, що дає можливість застосовувати педагогічний менеджмент у навчально-виховному процесі, сприяти самоуправлінню курсантів у навчальній діяльності. У зв'язку 3 цим в організаційному та методичному аспектах важливим $\epsilon$ розподіл обов'язків i відповідальності між педагогами та курсантами, оскільки такий підхід формує суб'єктність учасників процесу навчання, сприяє набуттю культури саморегуляції навчальної діяльності курсантів на формуванню в них основних елементів управлінської діяльності - самомотивування, самоорганізації, реалізації навчальної діяльності та самоконтроль. Результатом їхньої реалізації є самоменеджмент курсантів у навчальній діяльності.

Ці підходи доповнюють такі методологічні принципи: системності, активності, розвитку, детермінізму, суб'єктності, єдності свідомості та діяльності.

Цільово-мотиваційний компонент визначає основну мету функціонування моделі, яка визначається на основі державного та соціального замовлення на професійну підготовку офіцерів пожежної безпеки. Мета реалізації моделі - формування управлінської компетентності у випускників ВНЗ МНС України, які набувають професійну освіту за напрямом 6.170203 «Пожежна безпека», здатних до професійної діяльності у складних екстремальних умовах природних i техногенних катастроф, спроможних приймати оптимальні рішення в екстремальних умовах. Основна мета - це управлінська підготовка 
офіцерів пожежної безпеки, які мають управлінське мислення, сформовану управлінську культуру i компетентність, здатні успішно реалізовувати управлінські функції в стандартних і екстремальних умовах професійної діяльності.

Вона визначає основні завдання щцодо формування управлінської компетентності майбутніх офріиерів пожежної безпеки: формування позитивного емоційно-ціннісного ставлення до майбутньої управлінської діяльності та іiі норм, правил і цінностей; формування мотиваційної, когнітивної та праксиологічної сфер майбутньої управлінської діяльності як основи управлінської культури; формування професійно важливих управлінських якостей та культури спільної діяльності, здатностей роботи в команді; набуття первинного досвіду управлінської діяльності на тих посадах, на які евентуально може бути призначений випускник після закінчення ВНЗ МНС України; формування управлінського мислення, рефлексивно-оціночних здатностей щодо усвідомлення та критичного оцінювання власного рівня управлінської компетентності.

Досягнення мети та реалізація завдань безпосередньо залежать від актуалізації мотиваційної сфери педагогів і курсантів, зміст якої складають інтереси, бажання, потреби та мотиви викладання педагогів, а також навчальної та майбутньої професійної діяльності курсантів. Безумовно, мотиваційна сфера курсантів має бути зорієнтована не тільки на актуальні завдання навчальної діяльності, а й на майбутню управлінську діяльність.

Змістовий компонент, з одного боку, визначається державним стандартом за напрямом 6.170203 «Пожежна безпека», на основі якого відбувається педагогічна взаємодія всіх суб'єктів навчального процесу в ВНЗ МНС України, а з іншого - має забезпечувати набуття випускниками управлінської компетентності як інтегрального результату їхньої професійної підготовки. Специфіка їх управлінської підготовки полягає в тому, що всі навчальні дисципліни, теоретична та практична підготовка здійснюють свій посильний внесок у формування управлінської компетентності. Але вона стихійно та оперативно не формується, а є інтегральним результатом всієї професійної підготовки. Відповідно, зміст начальних дисциплін і методика їх викладання, методика практик і стажування потребує переосмислення в контексті інтегрального результату їх професійної підготовки - набуття управлінської компетентності. Зміст управлінської підготовки має бути диференційований на основних етапах формування управлінської компетентності, конкретизований у змісті відповідних навчальних дисциплінах, звертаючи увагу на формування того чи іншого компонента цієї компетентності.

У зв'язку з цим зміст управлінської підготовки має: відповідати завданням формування управлінської компетентності у майбутніх офіцерів пожежної безпеки, зокрема набуттю системності, гнучкості та творчості мислення; сприяти формуванню в них управлінської культури, основу яких складають управлінські знання; сприяти набуттю ними досвіду розв'язання управлінських задач і завдань різного ступеня складності; сприяти вихованню професійно важливих управлінських якостей, позитивного ставлення до майбутньої управлінської діяльності.

Аналіз навчального плану підготовки випускників за напрямом 6.170203 «Пожежна безпека» та за спеціальностями 7.17020301, 8.17020301 «Пожежна безпека» показує, що зміст їх підготовки в основному відповідає державному стандарту. Але є й суттєві резерви - це уточнення змісту окремих модулів і надання їм управлінського спрямування, вдосконалення методик викладання окремих навчальних дисциплін в управлінському спрямуванні, підсилення міждисциплінарних змістових зв'язків.

Організаційно-діяльнісний компонент, необхідність якого зумовлено тим, що управлінська компетентність $є$ інтегральним результатом всієї професійної підготовки випускників за напрямом 6.170203 «Пожежна безпека» та підсумковим показником діяльності всього науково-педагогічного складу ВНЗ МНС України. У зв’язку з цим необхідною $\epsilon$ системна організаційна робота на рівні ВНЗ щодо організаційнопедагогічного забезпечення формування управлінської компетентності випускників за видами підготовки, за основними видами навчальних заходів, на факультетах і кафедрах. 
Діяльнісний складник містить різноманітні доцільні форми, методи, способи та види управлінської підготовки, результатом якої $\epsilon$ сформованість управлінської компетентності. Більшість форм і методів навчання $є$ універсальними, які є характерними для системи вищої освіти, оскільки вони містять суттєвий освітній потенціал щодо формування управлінської компетентності. Найголовніше - це залучення курсантів до активної навчальної діяльності на всіх заняттях як їх суб'єктів. При цьому характер навчальної діяльності має передбачати конкретну практичну діяльність, що стимулює цілеспрямоване формування основних складників їх управлінської компетентності, актуалізує життєвий, навчальний і професійний досвід, поетапно веде від одного рівня до наступного - більш високого рівня сформованості управлінської компетентності. Наприклад, ефективним засобом є квазіуправлінські завдання різної складності - від простих до комплексних, які розв'язуються курсантами, наприклад, на комплексних тактико-спеціальних навчаннях із попередження та ліквідації надзвичайних ситуацій природного та техногенного характеру на воді та під водою, гасіння газових свердловин, розливів нафти та резервуарів зі скрапленим газом, пожеж на відкритих технологічних установках, гасіння пожеж лісового та торф'яного масивів, організації пошуку, знешкодження та знищення вибухонебезпечних предметів, пошуку потерпілих під завалами із залученням кінологічної служби тощо.

Суттєві резерви у формуванні управлінської компетентності має практична підготовка, яка організується і проводиться згідно 3 «Положенням про організацію та проведення практичної підготовки курсантів, студентів (слухачів) вищих навчальних закладів МНС України», затвердженого наказом МНС України від 01.12.2003 р. № 461. Вона складає, на нашу думку, основу практичного набуття досвіду управлінської діяльності майбутнього фахівця оперативно-рятувальної служби цивільного захисту України, оскільки більшість практичних занять проходять у безпосередньому контакті 3 вогнем на полігонах $\mathrm{i}$ в навчальних центрах, із застосуванням бойової техніки навчальної пожежно-рятувальної частини. У зв'язку з цим є доцільним покращення методик і технологій практичних занять 3 формування навичок, умінь і здатностей щодо проведення аварійно-рятувальних робіт в умовах надзвичайних ситуацій, зокрема, проведення пошуково-рятувальних робіт із завалів, при промислових аваріях із виходом сильнодіючих отруйних речовин, при ліквідації аварій $\mathrm{i}$ дорожньо-транспортних пригод на транспорті, рятування із затоплених споруд $\mathrm{i}$ на водоймищах тощо. Отже, просте збільшення годин не дасть жодного ефекту, коли немає чітких навчальних, виховних, формувальних і розвивальних цілей практичної підготовки. У зв'язку з цим має бути методологічно обгрунтованою послідовність основних етапів практичної підготовки курсантів, під час яких формуються навички, вміння, здатності, закріплюються теоретичні знання, професійно важливі якості управлінця. Нині курсанти на кожному курсі проходять практику, а на випускних курсах - стажування, що дозволяє реалізувати істотний педагогічний потенціал щодо формування управлінської компетентності.

Пропедевтичний етап розпочинається на етапі вступу до ВНЗ і завершується на другому курсі. Суттєвий мотиваційний потенціал містить ознайомлювальна навчальна практика на посаді пожежника-рятувальника безпосередньо в пожежно-рятувальних частинах після першого курсу навчання, яка надає змогу курсантам переконатися в необхідності набуття управлінської компетентності. На другому курсі вони проходять навчальну практику на посаді пожежника в навчальній пожежно-рятувальній частині (не менше двадцяти п'яти чергувань), після чого - навчальну практику на посаді пожежника-рятувальника безпосередньо в пожежних частинах, де у складі караулів виїжджають на гасіння реальних пожеж, беруть участь у ліквідації аварій техногенного та природного характеру. Цей етап має підкріплювати мотивацію вибору фаху офіцера пожежної безпеки, сприяти набуттю навичок і вмінь роботи в команді, продемонструвати роль управлінських знань у професійній діяльності офіцера. 
Професійно-орієнтований етап. Безпосередня професійно-спрямована робота 3 формування практичного складника управлінської компетентності має розпочинатися на третьому курсі, коли курсанти проходять практику на посаді командира відділення в навчальній пожежно-рятувальній частині (5-6 чергувань) і по завершенню навчання на третьому курсі - навчальну практику на посаді командира відділення у пожежнорятувальній частині підрозділу МНС України.

Суб'єктно-діяльнісний етап, який проводиться на четвертому курсі в процесі стажування курсантів на посадах начальника караулу в підрозділах МНС України та Державного інспектора у сфері нагляду за пожежною та техногенною безпекою Держтехногенбезпеки України. На п’ятому курсі під час навчання за освітньо-професійними програмами підготовки «Спеціалістів» і «Магістрів» організується навчальна практика та стажування на посадах інженерного складу органів управління оперативно-рятувальної служби цивільного захисту та Держтехногенбезпеки України. Мета - формування суб'єкта управлінської діяльності в підрозділах МНС України.

Діагностичний компонент представлений у формі основних критеріїв сформованості управлінської компетентності майбутніх офіцерів пожежної безпеки - ціннісномотиваційним, гностичним, операційно-управлінським, емоційно-вольовим, суб'єктним критеріями та професійно важливими якостями.

Результативний складник відображає реалізацію цільово-мотиваційного компонента, основним критерієм якого $є$ сформованість управлінської компетентності за всіма показниками. Зміст цього компонента визначається за допомогою критеріїв і показників сформованості управлінської компетентності майбутніх офіцерів пожежної безпеки.

Інтегральним компонентом моделі є суб'єктний, який, 3 одного боку, підкреслює необхідність актуалізації суб'єктного потенціалу курсантів у навчальній діяльності та у формуванні управлінської компетентності, а з іншого, - демонструє досягнення головного результату їх управлінської підготовки - становлення суб'єктом управлінської діяльності.

Успішній реалізації моделі формування управлінської компетентності майбутніх офіцерів пожежної безпеки сприяє дотримання комплексу таких організаційнопедагогічних умов:

- творче поєднання основних видів, форм, методів і засобів управлінської підготовки майбутніх офіцерів пожежної безпеки та іiі психолого-педагогічний супровід, що передбачає чітку координацію їх професійної підготовки на рівні ректорату, командування факультетів, начальників кафедр і конкретних педагогів;

- актуалізація суб'єктного потенціалу курсантів у навчально-виховному процесі ВН3 МНС України, що є безпосередньою умовою активізації їх мисленнєвих процесів, формування ціннісного ставлення до майбутньої управлінської діяльності в системі МНС України та до отриманих результатів своєї навчальної діяльності, сприяння іiі саморегуляції та самодетермінації, а також рефлексії та саморефлексії як суб'єктів навчальної та майбутньої управлінської діяльності;

- формування у курсантів чіткого уявлення про сутність, зміст i структуру управлінської компетентності майбутніх офіцерів пожежної безпеки та необхідності їі опанування в процесі професійної підготовки;

- наявність міждисциплінарної методики формування управлінської компетентності у майбутніх офіцерів пожежної безпеки у процесі професійної підготовки, яка має частково реалізовуватися у процесі вивчення кожної окремої навчальної дисципліни, а повністю - в процесі комплексних тактико-спеціальних навчань, що має надати змогу варіювання видами, методами, способами, формами та засобами формування управлінської компетентності;

- упровадження в навчальний процес квазіуправлінських завдань різної складності репродуктивних, продуктивних, частково-пошукових і творчих; 
- підвищення кваліфікації педагогів у питанні формування управлінської підготовки майбутніх офіцерів пожежної безпеки, навчально-методичне забезпечення та супроводження ними самостійної роботи курсантів.

Перспективні напрями подальших наукових пошуків: обгрунтування міждисциплінарної методики формування управлінської компетентності майбутніх офіцерів пожежної безпеки в процесі професійної підготовки.

\title{
Література
}

1. Новиков А. М. Методология научного исследования : [учебно-метод. пособие] / А. М. Новиков, Д. А. Новиков. - М. : Либроком, 2010. - 280 с. 2. Наказ Міністерства України з питань надзвичайних ситуацій та у справах захисту населення від наслідків Чорнобильської катастрофи з 01.12.2009 № 808 «Про затвердження Довідника кваліфікаційних характеристик професій працівників МНС України»[Електронний ресурс]. - Режим доступу: http://zakon.nau.ua/doc/?uid=1041.38208.1\&nobreak=1

УДК 37.016:51

\author{
В. В. Корольський, \\ кандидат техн. наук, професор, \\ A. М. Капіносов, \\ кандидат пед. наук, ст. викладач, \\ Криворізький педагогічний інститут \\ ДВНЗ «Криворізький національний університет»
}

\section{МАТЕМАТИЧНА АЛГОРИТМІЧНА КОМПЕТЕНТНІСТЬ: ТЕОРЕТИКО-МЕТОДИЧНІ ОСНОВИ ФОРМУВАННЯ, СТРУКТУРА ТА РІВНІ}

Корольський В. В., Капіносов А. М. Математична алгоритмічна компетентність: теоретикометодичні основи формування, структура та рівні.

У статті розкрито теоретико-методичні основи формування алгоритмічної компетентності як виду математичної компетентності, визначено її структуру і рівні.

Ключові слова: математична компетентність, алгоритмічна компетентність, алгоритм, алгоритмічне мислення, алгоритмічна культура, структура алгоритмічної компетентності, рівні алгоритмічної компетентності.

Корольський В. В., Капиносов А. Н. Математическая алгоритмическая компетентность: теоретико-методические основы формирования, структура и уровни.

В статье раскрыты теоретико-методические основы формирования алгоритмической компетентности как вида математической компетентности, определены ее структура и уровни.

Ключевые слова: математическая компетентность, алгоритмическая компетентность, алгоритм, алгоритмическое мышление, алгоритмическая культура, структура алгоритмической компетентности, уровни алгоритмической компетентности.

Korolsky V. V. Kapinosov A. M. Algorithmic mathematical competence: theoretical and methodological basis for the formation, structure and levels.

The article presents theory-and-methodological bases for the formationof algorithmic competenceas a type of mathematical competence is closed its structure and levels.

Key words: mathematical competence, algorithmic competence, algorithm, algorithmic thinking,algorithmic culture, the structure of algorithmic competenc elevels of algorithmic competence.

Розбудова математичної освіти на засадах компетентнісного підходу передбачає виокремлення видів математичної предметної компетентності, розкриття їх структури, рівнів та розроблення теоретико-методичних основ формування.

У науково-методичній літературі виокремлено п’ять складників математичної компетентності: понятійна, алгоритмічна (процедурна), дослідницька, технологічна i методологічна компетентності. Їх характеристики, показники вияву подано у працях Ю. Захарійченка, О. Школьного [3], М. Зелмана, О. Ляшенко, С. Ракова [7]. Водночас структура, рівні названих вище компетенцій не розглядалися. Крім того, деякі з видів 